\title{
A TRAJETÓRIA DAS TAXAS DE ALFABETIZAÇÃO NO BRASIL NAS DÉCADAS DE 1990 E 2000*
}

\author{
Alceu Ravanello Ferraro**
}

\begin{abstract}
RESUMO: O artigo analisa o andar da alfabetização no Brasil nas décadas de 1990 e 2000, com base nos microdados de uma série de PNAD e dos Censos Demográficos de 1991 e 2000. Discutidas a utilidade do conceito censitário de alfabetização e a importância da noção de analfabetismo infantil, o texto demonstra, primeiro, como as desigualdades quanto à alfabetização se constituem na largada do processo de escolarização, passando, então, à análise das trajetórias da taxa de alfabetização, dos diferentes níveis de educação básica e da taxa de alfabetização por sexo e cor ou raça. Introduz, por fim, a variável classe social, cruzada com sexo e raça. Na conclusão, o texto ressalta novamente que é logo na largada do processo de escolarização fundamental que se estabelecem as desigualdades quanto à alfabetização e aponta para alguns desafios ainda postos à alfabetização e escolarização no Brasil.
\end{abstract}

Palavras-chave: Alfabetização. Escolarização. Gênero. Raça. Classe social.

\section{The EVolution of LITERACY RATES IN BRAZIL IN THE 1990S}

AND THE 2000s

\begin{abstract}
Based on the microdata of a series of PNADs (Pesquisas Nacionais por Amostra de Domicílios - National Household Sample Survey) and of the 1991 and 2000 Demographic Censuses, this paper analyzes the development of literacy in Brazil in the 1990s and 2000s. After discussing the use of the census concept of literacy and the importance of the notion of child illiteracy, the text demonstrates that inequalities as for literacy build up at the very beginning of schooling. It then analyses the evolution of the literacy rates at different basic education levels, before sorting them by sex and color or race. It finally introduces the social class variable, which it crosses with those of "sex" and "race". It concludes by insisting that literacy inequalities appear at the very beginning of fundamental schooling and by pointing out some challenges the literacy and schooling still have to face in Brazil.
\end{abstract}

Key words: Literacy. Schooling. Gender. Race. Social class.

Trabalho desenvolvido com apoio do cNPq, com participação sempre pronta e competente do bolsista de Apoio Técnico, Jasom de Oliveira, Bacharel em Teologia (2009), Faculdades Est, São Leopoldo (RS).

** Doutor em Ciências Sociais e docente convidado do Programa de Pós-Graduação em Educação da Universidade Federal do Rio Grande do Sul (UFRGS). E-mail: aferraro@adufrgs.ufrgs.br 


\title{
L'ÉVOLUTION DES TAUX D'ALPHABÉTISATION AU BRÉSIL DANS LES ANNÉES 1990 ET 2000
}

\begin{abstract}
RÉSUMÉ: Cet article analyse la progression de l'alphabétisation au Brésil entre 1990 et 2000 sur les bases des microdonnées provenant d'une série de P.N.A.D. (Pesquisas Nacionais por Amostra de Domicílios - Enquête nationale par sondage sur les ménages) et des recensements de 1991 et 2000. Après avoir discuté l'utilité du concept d'alphabétisation utilisés par ces derniers et l'importance de la notion d'analphabétisme infantile, le texte commence par montrer comment les inégalités en termes d'alphabétisation se constituent dès le début du processus de scolarisation, avant d'analyser l'évolution du taux d'alphabétisation des différents niveaux d'éducation de base et de les trier par sexe et couleur ou race. Il introduit finalement la variable classe sociale, qu'il croise avec celles de sexe et de race. Sa conclusion réitère que c'est bien dès le début du processus de scolarisation fondamental que les inégalités devant l'alphabétisation s'établissent et il indique certains défis qui se posent encore à l'alphabétisation et à la scolarisation au Brésil.
\end{abstract}

Mots-clés: Alphabétisation. Scolarisation. Genre. Race. Classe sociale.

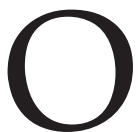

objetivo deste artigo é tão somente a análise do andar da alfabetização no Brasil nas décadas de 1990 e 2000, ${ }^{1}$ com base principalmente numa série de Pesquisas Nacionais por Amostra de Domicílios (PNAD), com recurso também aos Censos Demográficos de 1991 e 2000, pesquisas estas conduzidas pelo Instituto Brasileiro de Geografia e Estatística (IBGE). Nesta perspectiva, a primeira questão a enfrentar é se ainda faz sentido trabalhar com o conceito de alfabetização, tal como utilizado pelo IBGE nos censos e PNAD.

\section{A alfabetização no sentido censitário ainda faz sentido?}

Anteriormente à prática de levantamentos censitários periódicos, a assinatura do próprio nome em documentos era utilizada como indicador de alfabetização, ao passo que a assinatura com uma cruz era tida como indicador de analfabetismo. Estudos já clássicos de Cipolla (1970) e de Furet e Ozouf (1977) valeram-se, no estudo da alfabetização, tanto desse conceito e parâmetro (a assinatura), como da definição censitária saber ler e escrever, que, no Brasil, esteve em vigor desde o primeiro censo, em 1872, até o censo de 1940. A diferença entre os dois conceitos e parâmetros é patente: a assinatura do próprio nome e a assinatura com uma cruz estão lá nos arquivos e podem ser conferidas por qualquer pesquisador; as respostas sim ou não à pergunta "Sabe ler e escrever?" não são mais que declarações da pessoa informante a respeito de cada um dos membros do domicílio, sem possibilidade de verificação da veracidade, seja da declaração, seja da anotação feita pelo recenseador. 
Por influência da Organização das Nações Unidas para a Educação, a Ciência e a Cultura (UNESCO), a partir do Censo de 1940 o IBGE introduziu nova definição, tida por aquele órgão como "mais rígida e precisa" que a anterior: "Como sabendo ler e escrever entendem-se as pessoas capazes de ler e escrever um bilhete simples, em um idioma qualquer, não sendo assim consideradas aquelas que apenas assinassem o próprio nome. Critério idêntico vigorou em relação ao Censo Demográfico de 1940" (IBGE, 1956, p. xIx). Com pequenas variações, esta definição se manteve até o último censo (de 2000), tendo vigorado inclusive nas PNAD. No Censo 2000 a definição é a seguinte: "Considerou-se como alfabetizada a pessoa capaz de ler e escrever um bilhete simples no idioma que conhecia. Aquela que aprendeu a ler e escrever, mas esqueceu e a que apenas assinava o próprio nome foi considerada analfabeta" (IBGE, 2001, p. 24).

Para o IBGE, essa mudança de conceito teria comprometido a comparabilidade das estatísticas produzidas a partir de 1950 com as dos censos anteriores, em virtude do critério mais rigoroso introduzido nesse ano² (IBGE, 1961, p. 391, nota 2). De qualquer forma, as análises a serem feitas adiante apoiam-se todas em estatísticas produzidas com base no conceito de alfabetização em vigor a partir de 1950, de sorte que o problema da comparabilidade com dados de censos anteriores a 1950 não se coloca no presente estudo.

A questão principal que aqui se levanta é se ainda faz sentido, no estudo da escolarização e alfabetização, recorrer-se a um indicador tão frágil como (a declaração de) saber ler e escrever um bilhete simples. Entende-se que o esclarecimento deste ponto é condição indispensável para se poder avançar no tema a abordar: o andar da alfabetização nas últimas duas décadas. Em relação a isto, a primeira consideração a fazer é que o censo, assim como outras pesquisas conduzidas pelo IBGE, como as PNAD, não testa se a pessoa informante e os membros do domicílio do informante sabem de fato ler e escrever. Vale a resposta sim ou não da pessoa entrevistada à pergunta posta pelo recenseador a respeito de cada membro do domicílio que tenha 5 anos ou mais. $O$ fato de, a partir do último quartel do século XIX, se haver transformado o analfabetismo num estigma (Ferraro, 2004 e 2009b; Ferraro \& Leão, 2009) pode levar as pessoas entrevistadas nos levantamentos censitários e amostrais a esconder essa condição, o que poderia resultar numa sub-representação do analfabetismo nas estatísticas oficiais.

A segunda questão tem a ver com o preceito constitucional que elevou o ensino fundamental completo à categoria de direito público subjetivo (Brasil, 1988). Diante disso, cabe, sim, a pergunta sobre qual o valor de um indicador construído a partir de uma declaração de que fulano ou fulana saber ler e escrever, quando é forçoso admitir que a obtenção da capacidade de leitura e escrita não constitui mais do que o primeiro passo no processo de escolarização obrigatória. A tal argumento responderia que, mesmo que este não seja mais do que o primeiro passo, ele se constitui, de fato, na condição necessária sem a qual não haverá segundo passo, nem qualquer outro, 
na caminhada escolar. Além disso, esse primeiro passo significa também livrar-se do rótulo negativo, do ferrete, do estigma, em que se transformou a condição de analfabetismo a partir das discussões havidas na Câmara e Senado do Império, nos anos de 1878 a 1881, discussões essas que culminaram na Lei Saraiva, de 9 de janeiro de 1981, a qual estabeleceu e sacramentou a incapacidade política de quem não soubesse ler e escrever, conforme referido anteriormente.

\section{Alfabetização e analfabetismo infantil}

A ênfase no andar da taxa de alfabetização já a partir dos grupos etários de $5 \mathrm{e}$ 6 anos de idade significa que, em contrapartida, se tem como fato e se assume como desafio o analfabetismo infantil. Quando o assunto é analfabetismo, firmou-se, por influência principalmente da UNESCO, a prática de considerar apenas aquele existente entre as pessoas de 15 anos ou mais, também chamado de analfabetismo adulto. Na realidade, analfabetismo de jovens e adultos. Mas, a propósito, vale lembrar que a própria unEsCo, em estudo do início da década de 1950, nas poucas páginas dedicadas ao Brasil, tendo por base os censos de 1920 e 1940, fazia uma observação de sumo interesse sobre o analfabetismo infantil:

É preocupante constatar que, no Brasil, a proporção de analfabetos entre as crianças em idade escolar (de 7 a 14 anos) é mais elevada do que entre os habitantes de mais de 15 anos, se bem que a taxa de diminuição do analfabetismo seja um pouco mais elevada no primeiro do que no segundo grupo. (Unesco, 1953, p. 42)

Nesse sentido, é esclarecedora a manifestação de Torres (1990, p. 513), sustentando que a redução do problema do analfabetismo à população adulta (de 15 anos ou mais) explica a dificuldade real que se tem para assumir o analfabetismo como "uma problemática enraizada na escolaridade infantil, vinculada às deficiências de acesso e qualidade da escola primária".

É por isso que, em assunto de alfabetização, vem-se tomando como ponto de partida nas análises a idade de 5 anos, como faz habitualmente o IBGE nos censos e nas PNAD. Tal procedimento se justifica não porque se deva esperar que crianças de 5 e 6 anos já se tenham alfabetizado, mas porque, de fato, crescente número delas é declarado como alfabetizado nos levantamentos do IBGE.

Vale, ainda, insistir num ponto. Chamar a atenção para o analfabetismo infantil entre crianças abaixo dos 10 anos de idade não significa que se concorde com a posição daqueles que, a título de priorizarem o ensino fundamental de crianças e adolescentes, minimizam e até tentam desconstituir o direito de jovens e adultos ao ensino fundamental. ${ }^{3}$ Afinal, o direito público subjetivo à educação fundamental assegurado pela Constituição (Brasil, 1988) é o mesmo para cada brasileiro e cada brasileira, 
independentemente da idade. Tal insistência apoia-se no entendimento de que a solução do problema do analfabetismo está na escolarização universal, a qual passa necessariamente pela universalização, pelo menos, da educação fundamental de crianças e adolescentes. No entanto, importa ressalvar que qualquer país ou região que tenha falhado na alfabetização de suas crianças terá que desenvolver programas alternativos de alfabetização e escolarização para jovens e adultos. Trata-se de um direito.

\section{As desigualdades quanto à alfabetização se constituem na largada do processo de escolarização}

A Tabela 1 e o Gráfico 1, construídos com base nos dados do Censo 2000 e aqui reproduzidos de estudo anterior (Ferraro, 2005, p. 76), permitem confrontar entre si as trajetórias das taxas de alfabetização de cinco unidades populacionais brasileiras, sempre para as pessoas de 5 a 14 anos. Essas unidades são: o Brasil como um todo, o estado do Rio Grande do Sul, o município gaúcho de Montauri, o estado de Alagoas e o município alagoano de Olho d'Água Grande. A razão dessas escolhas é simples: no censo anterior (1991), o Rio Grande do Sul era o estado mais alfabetizado, e Montauri, junto com Poço das Antas, o município gaúcho com taxa máxima de alfabetização $(100 \%)$ já entre as crianças de 8 anos de idade; Alagoas, por sua vez, era o estado brasileiro menos alfabetizado, e Olho d'Água Grande, o município alagoano com a menor taxa de alfabetização entre crianças de 8 anos (Ferraro, 1999, p. 193, Gráfico 1).

A primeira revelação da tabela e gráfico referidos é que as desigualdades entre as trajetórias das taxas de alfabetização dos 5 aos 14 anos começam a delinear-se, para as diferentes unidades populacionais consideradas, já entre as crianças de 6 anos de idade. Com efeito, a taxa de alfabetização varia, nessa idade, de um mínimo de apenas 4,4\% em Olho d'Água Grande a um máximo de cerca de 30\% para Brasil, Rio Grande do Sul e Montauri.

A segunda revelação é que, dos 6 para os 7 anos, essas desigualdades se ampliam e se definem, formando uma escala de alfabetização que parte de um mínimo de 8,6\% em Olho d'Água Grande e de 32,5\% em Alagoas, e se eleva sucessivamente, a partir daí, para 59,7\% no conjunto do Brasil, 76,0\% no Rio Grande do Sul e 87,5\% em Montauri. Uma variação ou desigualdade que vai, de um extremo ao outro, de pouco menos de $9 \%$ a quase $90 \%$. Isto, para as crianças de 7 anos.

A terceira revelação é que, dos 7 para os 8 anos, as taxas de alfabetização aumentam um pouco em todas as unidades populacionais consideradas, alcançando $26,9 \%$ em Olho d'Água Grande, 45,9\% em Alagoas, 76,1\% no Brasil, 92,8\% no Rio Grande do Sul e $100 \%$ em Montauri. Em que pese esse avanço generalizado da taxa de alfabetização dos 7 para os 8 anos de idade, mantêm-se elevadíssimas as desigualdades entre as cinco unidades populacionais. 


\section{Tabela 1}

Trajetória da taxa de alfabetização entre as pessoas de 5 a 14 anos, segundo a idade.

Brasil e estados e municípios selecionados, 2000.

\begin{tabular}{|c|r|r|r|r|c|}
\hline \multicolumn{7}{|c|}{ Taxa de alfabetização (\%) } \\
\hline Idade & BR & RS & AL & $\begin{array}{c}\text { Montauri } \\
\text { RS }\end{array}$ & $\begin{array}{c}\text { Olho d'Água } \\
\text { Grande AL }\end{array}$ \\
\hline 5 anos & 8,8 & 5,3 & 6,6 & 0,0 & 2,2 \\
6 anos & 28,9 & 29,6 & 17,9 & 30,0 & 4,1 \\
7 anos & 59,7 & 76,0 & 32,5 & 87,5 & 8,6 \\
8 anos & 76,1 & 92,8 & 45,9 & 100,0 & 26,9 \\
9 anos & 84,4 & 96,6 & 58,6 & 100,0 & 28,7 \\
10 anos & 88,6 & 97,9 & 67,0 & 100,0 & 50,3 \\
11 anos & 91,8 & 98,4 & 74,5 & 100,0 & 52,3 \\
12 anos & 93,3 & 98,5 & 78,5 & 96,9 & 60,6 \\
13 anos & 94,6 & 98,7 & 82,1 & 100,0 & 62,8 \\
14 anos & 95,2 & 98,7 & 83,4 & 100,0 & 64,6 \\
\hline
\end{tabular}

Fonte: IBGE, Censo Demográfico 2000.

\section{Gráfico 1}

Trajetória da taxa de alfabetização entre as pessoas de 5 a 14 anos, segundo a idade.

Brasil e estados e municípios selecionados, 2000.
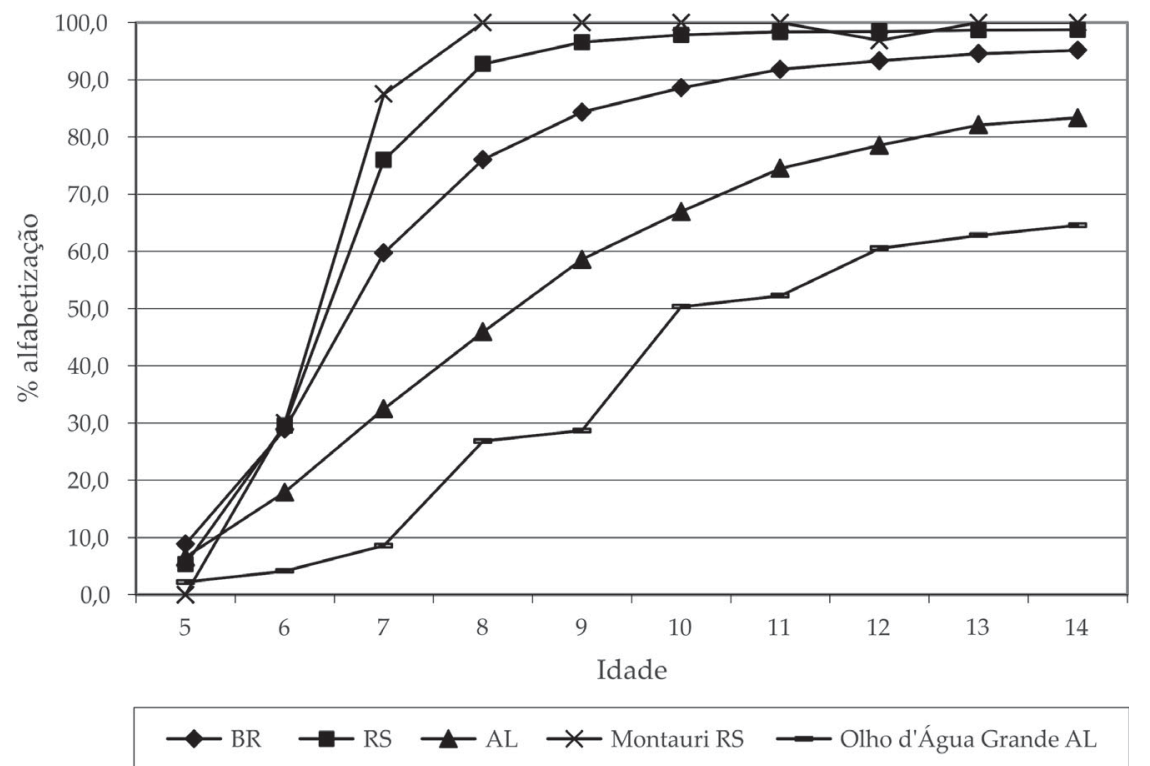

Fonte: Tabela 1. 
A quarta revelação está no fato de que o encurtamento das desigualdades que se opera a partir dos 9 anos: a) é lento e extremamente modesto e b) é até irrelevante, porquanto se deve mais ao fato de as unidades populacionais mais céleres terem atingido o topo (100\%) ou estarem aproximando-se desse nível, do que a avanços significativos das unidades mais lentas no processo de alfabetização. É isso que leva a dizer que as desigualdades quanto à alfabetização podem ser dadas como já estabelecidas entre as crianças de 7 anos e consolidadas entre as de 8 anos de idade. A partir desta idade, as desigualdades podem ser atenuadas, sim, na medida em que as unidades mais velozes forem atingindo ou aproximando-se de 100\% de alfabetização, mas dificilmente superadas.

Sintetizando, poder-se-ia dizer que a corrida da alfabetização se decide na largada do processo de escolarização, estando já selada a sorte aos 7 anos de idade e consolidada aos 8 anos. Na medida em que se generalize para toda a população recenseada de 5 a 14 anos o início da escolarização aos 6 anos, com um ensino fundamental de 9 anos, ${ }^{4}$ o momento definidor - aquele em que se estabelecem as desigualdades quanto à alfabetização - com muita probabilidade irá se antecipar dos 7 para os 6 anos.

É tudo isso que justifica dar-se especial atenção ao analfabetismo infantil e ao andar da taxa de alfabetização no grupo etário de escolarização obrigatória. Cada vez mais, o estigma do analfabetismo - no sentido de ignorância, de cegueira, de dependência, de incapacidade... - estará ferreteando a criança que, aos 8 anos (em breve, aos 7 anos), não tenha ainda conseguido dar esse primeiro passo no processo de escolarização, que é a alfabetização no sentido censitário de ler e escrever um bilhete simples. Com tendência, como já se observou, de essa idade baixar de 8 para 7 anos.

\section{Trajetória da alfabetização de 1991 a 2007}

No item anterior avaliou-se, com base no Censo 2000, a situação das crianças e adolescentes de 5 até 14 anos em termos de alfabetização. Trata-se, agora, de avaliar o andar da alfabetização nas décadas 1990 e 2000. A análise inicia tentando captar o movimento da alfabetização nos períodos que vão do Censo de 1991 ao Censo de 2000 e deste à PNAD de 2007, tendo por base a Tabela 2 e o Gráfico 2.

A primeira coisa que se observa é que, nas idades mais jovens (5 e 6 anos), o avanço da taxa de alfabetização foi bastante acentuado, tanto no novênio 1991/2000 quanto no setênio 2000/2007, passando a referida taxa, sucessivamente, de 5,6\% para $10,9 \%$ e 18,1\%, entre as crianças brasileiras de 5 anos de idade, e de 17,2\% para 33,3\% e 45,3\% entre as crianças brasileiras de 6 anos. A partir dos 7 anos, a melhora nos índices de alfabetização foi mais acentuada no período de 1991 a 2000 do que no de 2000 a 2007. Por exemplo, entre as crianças de 7 anos, a taxa, que subira de 45,6\% em 1991 para $64,0 \%$ em 2000, de 2000 a 2007 aumentou apenas para $70,6 \%$. 
Tabela 2

Trajetória da taxa de alfabetização entre as pessoas de 5 a 14 anos, segundo a idade. Brasil, Censos 1991 e 2000 e PNAD 2007.

\begin{tabular}{|c|ccc|}
\hline \multirow{2}{*}{ Idade } & \multicolumn{3}{|c|}{ Taxa de alfabetização (\%) } \\
\cline { 2 - 4 } & Censo 1991 & Censo 2000 & PNAD 2007 \\
\hline 5 anos & 5,6 & 10,9 & 18,1 \\
6 anos & 17,2 & 33,3 & 45,3 \\
7 anos & 45,6 & 64,0 & 70,6 \\
8 anos & 62,7 & 78,8 & 85,5 \\
9 anos & 72,1 & 86,0 & 91,0 \\
10 anos & 78,4 & 90,4 & 94,4 \\
11 anos & 82,1 & 93,2 & 96,1 \\
12 anos & 84,9 & 94,8 & 97,5 \\
13 anos & 86,8 & 95,7 & 98,1 \\
14 anos & 88,1 & 96,2 & 98,4 \\
\hline
\end{tabular}

Fontes: IBGE. Censos Demográficos 1991 e 2000; IBGE, PNAD 2007. Microdados.

\section{Gráfico 2}

Trajetória da taxa de alfabetização entre as pessoas de 5 a 14 anos, segundo a idade. Brasil, Censos 1991 e 2000 e PNAD 2007.

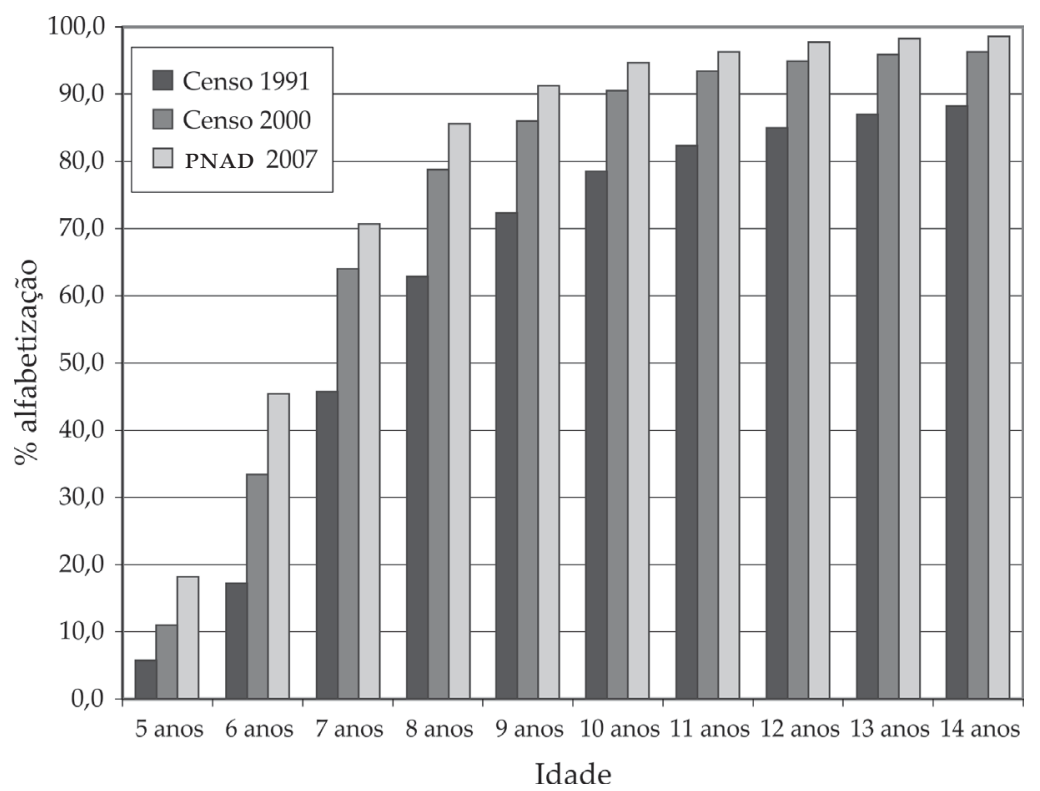

Fonte: Tabela 2. 
Alguns elementos precisariam ser levados em conta ao se querer explicar essa desaceleração no aumento da taxa de alfabetização no segundo período em relação ao primeiro: a) de 2000 e 2007, tem-se um período mais curto, de sete anos apenas, contra nove anos no período de 1991 a 2000; b) é mais fácil aumentar a taxa nos níveis menos elevados de alfabetização do que nos níveis mais elevados; c) a PNAD de 2007 apresenta taxas de alfabetização de um modo geral inferiores às das PNAD anteriores, como a de 2006 , o que poderia ser resultado de uma subestimativa da alfabetização na PNAD de $2007 .{ }^{5}$

Este último ponto (a suspeita em relação aos dados da PNAD de 2007 quanto à alfabetização) levou-nos a recorrer a novos processamentos na tentativa de esclarecer a questão. A ideia inicial era estabelecer períodos com intervalos de quatro anos, considerando apenas as PNAD de 1995 (primeiro ano do primeiro governo FHC), 1999 (primeiro ano do segundo governo FHC), 2003 (primeiro ano do primeiro governo Lula) e 2007 (primeiro ano do segundo governo Lula). Os resultados desse processamento aconselharam a introduzir na tabela e gráfico também as PNAD de 1990 e 1992, no sentido de verificar em que medida o movimento ascendente, verificado antes, se teria manifestado já na primeira metade da década de 1990.

Os resultados do processamento das seis PNAD escolhidas aparecem na Tabela 3 e no Gráfico 3. Tendo este gráfico como referência, evidenciam-se logo algumas situações: a) a taxa de alfabetização aumentou sensível e continuadamente, a cada PNAD, em todo o período de 1990 até 2007 ; b) os aumentos proporcionalmente maiores e mais regulares ocorreram nos grupos de 5 anos, onde a taxa inicial (3,6\% em 1990) se viu multiplicada por cinco (18,1\% em 2007), e no grupo de 6 anos, onde a taxa inicial (15,3\% em 1990) se multiplicou por três (45,3\% em 2007); c) os aumentos foram mais acentuados na década de 1990 do que na de 2000, com destaque para o quinquênio 1990/1995, a maior parte dele anterior ao primeiro governo FHC; d) por fim, o menor aumento verificou-se no último subperíodo (2003-2007), no governo Lula.

No entanto, é necessário ter cautela em relação a esta última observação. Das pesquisas consideradas na Tabela 3 e no Gráfico 3, a PNAD de 2007 foi a única que teve incluída na amostra a população rural dos estados de Rondônia, Acre, Amazonas, Roraima, Pará e Amapá, fato que deve ter forçado para baixo, em alguma medida, a taxa de alfabetização apurada nesse ano. Até a PNAD de 2003, inclusive, a população rural desses estados não foi contemplada nessas pesquisas do IBGE. 


\section{Trajetórias dos diferentes patamares da educação básica}

Quanto mais se afastam de zero e se aproximam de $100 \%$, tanto menos as taxas de alfabetização se prestam para revelar as desigualdades educacionais. A Tabela 4 e o Gráfico 4 introduzem outro critério de analfabetismo e alfabetização, com resultado muito próximo ao obtido com o critério saber ler e escrever. Com base na informação sobre anos de estudo concluídos com aprovação, O IBGE classifica a população em várias categorias ou patamares dentro do conjunto compreendido pela educação básica. A categoria dos Sem instrução e menos de 1 ano de estudo constitui praticamente um equivalente conceitual e numérico da categoria analfabetos/as (não saber ler e escrever um bilhete simples). As quatro categorias ( 1 a 3, 4 a 7, 8 a 10 e 11 anos ou mais de estudo) constituem, juntas, um equivalente da categoria alfabetizados/as. Todavia, com a vantagem de se poder distinguir níveis de escolarização. A expectativa é de que essa maneira de avaliar o fenômeno permita captar com mais precisão o andar da alfabetização/escolarização nos cinco diferentes períodos, que vão, no caso, de 1992 a 2007. Note-se que o primeiro período compreende apenas três anos, contra quatro anos nos demais períodos.

\section{Tabela 3}

Trajetória da taxa de alfabetização entre as pessoas de 5 a 14 anos, segundo a idade.

Brasil, 1990 a 2007.

\begin{tabular}{|c|c|c|c|c|c|c|}
\hline \multirow{2}{*}{ Idade } & \multicolumn{5}{|c|}{ Taxa de alfabetização (\%) } \\
\cline { 2 - 7 } & PNAD 1990 & PNAD 1992 & PNAD 1995 & PNAD 1999 & PNAD 2003 & PNAD 2007 \\
\hline 5 anos & 3,6 & 7,6 & 9,2 & 13,2 & 17,2 & 18,1 \\
6 anos & 15,3 & 23,2 & 27,2 & 34,1 & 38,7 & 45,3 \\
7 anos & 44,6 & 51,7 & 56,1 & 65,5 & 68,4 & 70,6 \\
8 anos & 62,5 & 68,6 & 72,4 & 81,0 & 83,4 & 85,5 \\
9 anos & 73,1 & 78,1 & 81,1 & 87,7 & 90,1 & 91,0 \\
10 anos & 80,0 & 83,4 & 86,1 & 91,6 & 93,7 & 94,4 \\
11 anos & 84,1 & 86,9 & 88,6 & 94,1 & 95,7 & 96,1 \\
12 anos & 86,7 & 88,8 & 91,6 & 95,3 & 97,2 & 97,5 \\
13 anos & 88,7 & 90,2 & 92,8 & 95,8 & 97,5 & 98,1 \\
14 anos & 90,3 & 91,8 & 93,7 & 96,6 & 98,0 & 98,4 \\
\hline
\end{tabular}

Fontes: IBGE, PNADs 1990, 1992, 1995, 1999, 2003 e 2007. Microdados. 


\section{Gráfico 3}

Trajetória da taxa de alfabetização entre as pessoas de 5 a 10 anos, segundo a idade.

Brasil, 1990 a 2007.

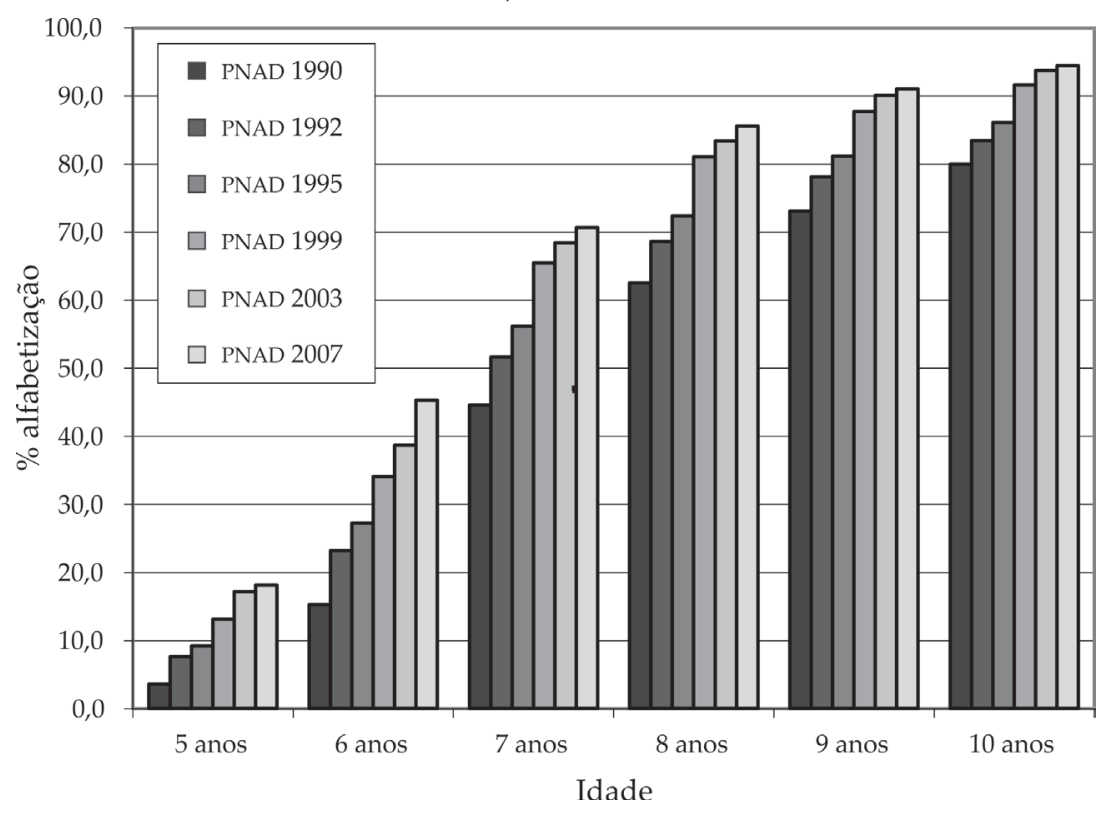

Fonte: Tabela 3.

A Tabela 4 e o Gráfico 4 contemplam apenas as pessoas de 18 a 24 anos. Nessa faixa de idade, todas poderiam ter concluído o ensino médio, equivalente a onze anos de estudo. Com maior razão, poderiam ter realizado com sucesso o mínimo constitucional, ou seja, ter concluído o ensino fundamental de oito anos de estudo, que talvez pudesse ser tomado como correspondente ao conceito de alfabetização funcional, embora se tenha restrição a esse conceito. O critério de quatro anos de estudo parece inadequado para tal fim. A análise pode ser feita a partir de duas perspectivas diferentes: dos ganhos conseguidos nos diferentes períodos e do ainda não realizado.

Nos quinze anos que vão de 1992 a 2007, os percentuais de pessoas situadas em cada uma das três categorias inferiores ao mínimo constitucional (oito anos de estudo) tiveram redução progressiva, com intensidade maior a partir de 1995 até 2007. Com efeito, a participação dos Sem instrução e menos de 1 ano de estudo caiu de 8,3\% para 2,8\%; a das pessoas com 1 a 3 anos de estudo (antigo primário incompleto) baixou de $13,8 \%$ para $4,3 \%$ e a das pessoas com 4 a 7 anos de estudo baixou de 38,0\% para $27,2 \%$. A participação conjunta das três categorias situadas abaixo do mínimo constitucional (fundamental completo), que somava 60\% em $1992(8,3 \%+13,8 \%+38,0 \%)$, ficou reduzida a $25,6 \%(2,8 \%+4,3 \%+18,5 \%)$ em 2007 - reduzida a menos de metade, portanto. 


\section{Tabela 4}

Pessoas de 18 a 24 anos, segundo o número de anos de estudo concluídos com aprovação.

Brasil, PNAD 1992, 1995, 1999, 2003 e 2007.

\begin{tabular}{|c|c|c|c|c|c|c|c|c|c|c|c|c|c|}
\hline \multirow{3}{*}{ Pesquisas } & \multicolumn{13}{|c|}{ Anos de estudo concluídos com aprovação } \\
\hline & \multirow[t]{2}{*}{ Total } & \multicolumn{2}{|c|}{$\begin{array}{c}\text { Sem } \\
\text { instrução ou } \\
\text { menos de } 1 \\
\text { ano }\end{array}$} & \multicolumn{2}{|c|}{1 a 3 anos } & \multicolumn{2}{|c|}{4 a 7 anos } & \multicolumn{2}{|c|}{8 a 10 anos } & \multicolumn{2}{|c|}{$\begin{array}{l}11 \text { anos ou } \\
\text { mais }\end{array}$} & \multicolumn{2}{|c|}{$\begin{array}{c}\text { Não } \\
\text { determi- } \\
\text { nados }\end{array}$} \\
\hline & & $\mathrm{N}^{\mathrm{o}}$ & $\%$ & $\mathrm{~N}^{\mathrm{o}}$ & $\%$ & № & $\%$ & $\mathrm{~N}^{\mathrm{o}}$ & $\%$ & № & $\%$ & № & $\%$ \\
\hline PNAD 1992 & 41.178 & 3.434 & 8,3 & 5.676 & 13,8 & 15.641 & 38,0 & 8.769 & 21,3 & 7.327 & 17,8 & 331 & 0,8 \\
\hline PNAD 1995 & 42.120 & 2.885 & 6,8 & 5.344 & 12,7 & 15.673 & 37,2 & 9.592 & 22,8 & 8.338 & 19,8 & 288 & 0,7 \\
\hline PNAD 1999 & 47.008 & 2.413 & 5,1 & 4.669 & 9,9 & 14.660 & 31,2 & 12.250 & 26,1 & 12.567 & 26,7 & 449 & 1,0 \\
\hline PNAD 2003 & 52.647 & 1.993 & 3,8 & 3.402 & 6,5 & 12.526 & 23,8 & 14.002 & 26,6 & 20.094 & 38,2 & 630 & 1,2 \\
\hline PNAD 2007 & 51.283 & 1.442 & 2,8 & 2.185 & 4,3 & 9.511 & 18,5 & 13.952 & 27,2 & 23.785 & 46,4 & 408 & 0,8 \\
\hline
\end{tabular}

Fontes: IBGE, PNAD 1992, 1995, 1999, 2003 e 2007. Microdados.

\section{Gráfico 4}

Pessoas de 18 a 24 anos, segundo o número de anos de estudo concluídos com aprovação. Brasil, PNAD 1992, 1995, 1999, 2003 e 2007.

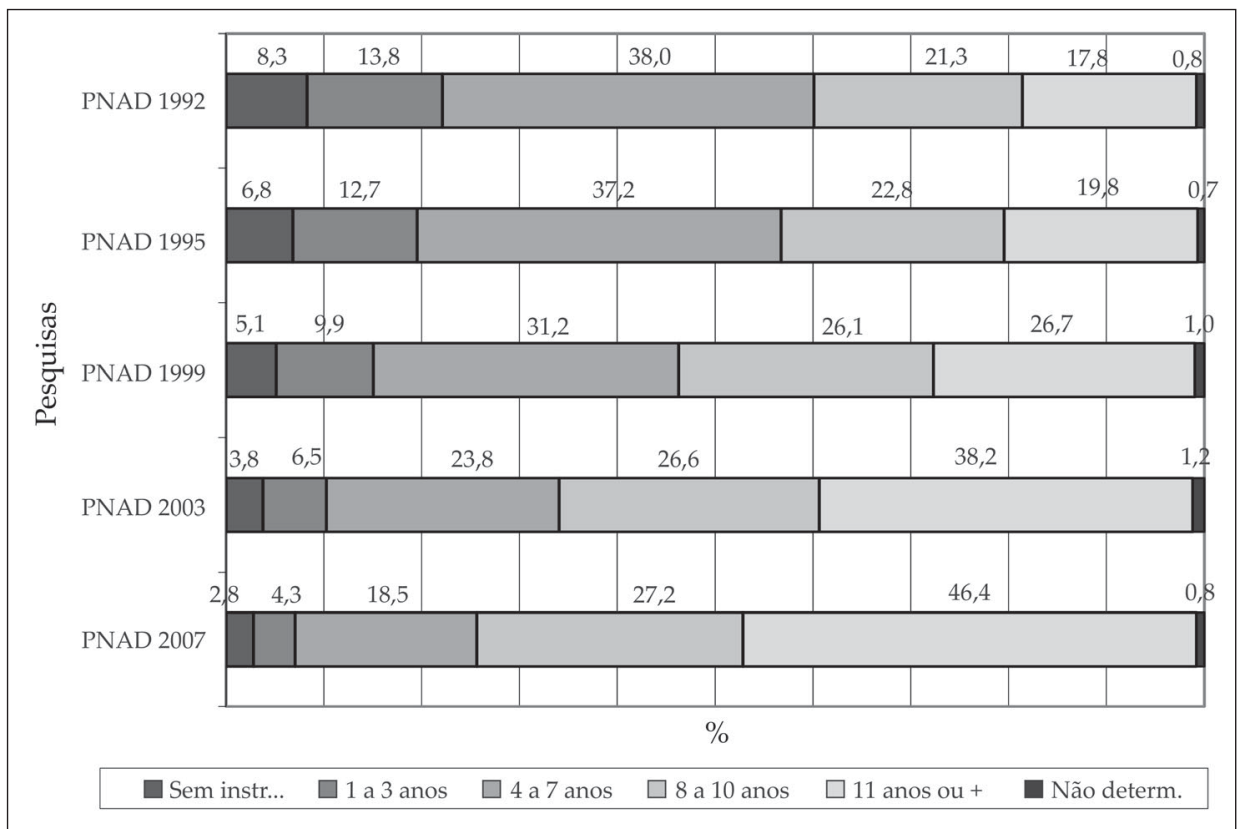

Fonte: Tabela 4. 
Vista a coisa pelo lado das categorias mais elevadas de anos de estudo, tem-se o seguinte: um pequeno aumento na categoria 8 a 10 anos de estudo (de 21,3\% para $27,2 \%$ ) e um forte aumento na categoria 11 anos ou mais (ensino médio concluído), cuja participação aumentou em 2,6 vezes, passando de 17,8\% em 1992 para 46,4\% em 2007. O Gráfico 4 permite ver que, a partir de 1995, os avanços nas categorias de oito a dez anos e onze ou mais anos de estudo obedeceram aproximadamente a um mesmo ritmo nos diferentes períodos que se seguiram.

Examinada, agora, a questão na perspectiva do ainda não realizado, tem-se o seguinte: apesar dos avanços verificados, em 2007, entre as pessoas de 18 a 24 anos, um quarto $(25,6 \%)$ não tinha ainda conseguido concluir o ensino fundamental, não chegando a $50 \%(46,4 \%)$ o número relativo das pessoas com ensino médio concluído (com onze anos ou mais de estudo). Este é um olhar dirigido para o desafio ainda posto, em contraposição ao olhar centrado nas conquistas obtidas.

\section{Trajetória da taxa de alfabetização por sexo e cor ou raça}

Nesta parte e na seguinte, o interesse volta-se para a relação entre as variáveis sexo, raça, classe social e alfabetização. Dada a multiplicidade de variáveis envolvidas, foi necessário limitar o estudo a um censo ou uma PNAD. Preferiu-se recorrer aos microdados do Censo de 2000.

Os gráficos 5 e 6, construídos com base nas tabelas 5 e 6, respectivamente, permitem confrontar entre si as taxas de alfabetização, primeiro, de homens e mulheres, depois, de brancos/as e negros/as. O Gráfico 5 proporciona três observações principais:

- Em todas as idades de 5 até 14 anos, as mulheres apresentam taxas de alfabetização mais elevadas do que os homens, o que confere com a tendência geral em termos dos mais variados indicadores educacionais no país.

- Partindo de um ponto percentual no início, a diferença em favor das mulheres cresce até aproximadamente cinco pontos percentuais de vantagem, reduzindo-se depois, a partir de 11 anos, por força da aproximação das taxas ao nível máximo (100\%).

- A elevação das taxas de alfabetização é muito lenta, no Brasil, para ambos os sexos. Com efeito, entre as crianças de 8 anos de idade, as taxas de alfabetização ficaram em apenas $81,4 \%$ entre as meninas e $76,3 \%$ entre os meninos, restando ainda por alfabetizar, nessa idade, aproximadamente uma em cada cinco meninas e um em cada quatro meninos. 


\section{Tabela 5}

Trajetória da taxa de alfabetização entre as pessoas de 5 a 14 anos, segundo a idade, por sexo.

Brasil, 2000.

\begin{tabular}{|c|c|r|r|r|r|c|}
\hline \multirow{2}{*}{ Idade } & \multicolumn{6}{|c|}{ Taxa de alfabetização (\%) } \\
\cline { 2 - 7 } & \multicolumn{7}{|c|}{ Homens } & \multicolumn{3}{c|}{ Mulheres } \\
\cline { 2 - 8 } & Total & Alfabet. & $\%$ & Total & Alfabet. & $\%$ \\
\hline \multirow{2}{*}{5 anos } & 1.739 .988 & 179.497 & 10,3 & 1.687 .529 & 195.752 & 11,6 \\
6 anos & 1.682 .175 & 534.875 & 31,8 & 1.629 .327 & 567.985 & 34,9 \\
7 anos & 1.675 .822 & 1.033 .673 & 61,7 & 1.631 .518 & 1.083 .876 & 66,4 \\
8 anos & 1.659 .280 & 1.265 .877 & 76,3 & 1.598 .543 & 1.300 .456 & 81,4 \\
9 anos & 1.662 .387 & 1.392 .847 & 83,8 & 1.609 .691 & 1.419 .725 & 88,2 \\
10 anos & 1.719 .615 & 1.517 .314 & 88,2 & 1.625 .740 & 1.507 .490 & 92,7 \\
11 anos & 1.755 .012 & 1.601 .430 & 91,2 & 1.696 .495 & 1.615 .546 & 95,2 \\
12 anos & 1.776 .054 & 1.655 .060 & 93,2 & 1.741 .866 & 1.679 .441 & 96,4 \\
13 anos & 1.741 .981 & 1.642 .231 & 94,3 & 1.730 .919 & 1.681 .468 & 97,1 \\
14 anos & 1.791 .179 & 1.699 .703 & 94,9 & 1.774 .823 & 1.729 .184 & 97,4 \\
\hline
\end{tabular}

Fonte: IBGE, Censo Demográfico 2000. Microdados.

\section{Gráfico 5}

Trajetória da taxa de alfabetização entre as pessoas de 5 a 14 anos, segundo a idade, por sexo. Brasil, 2000.

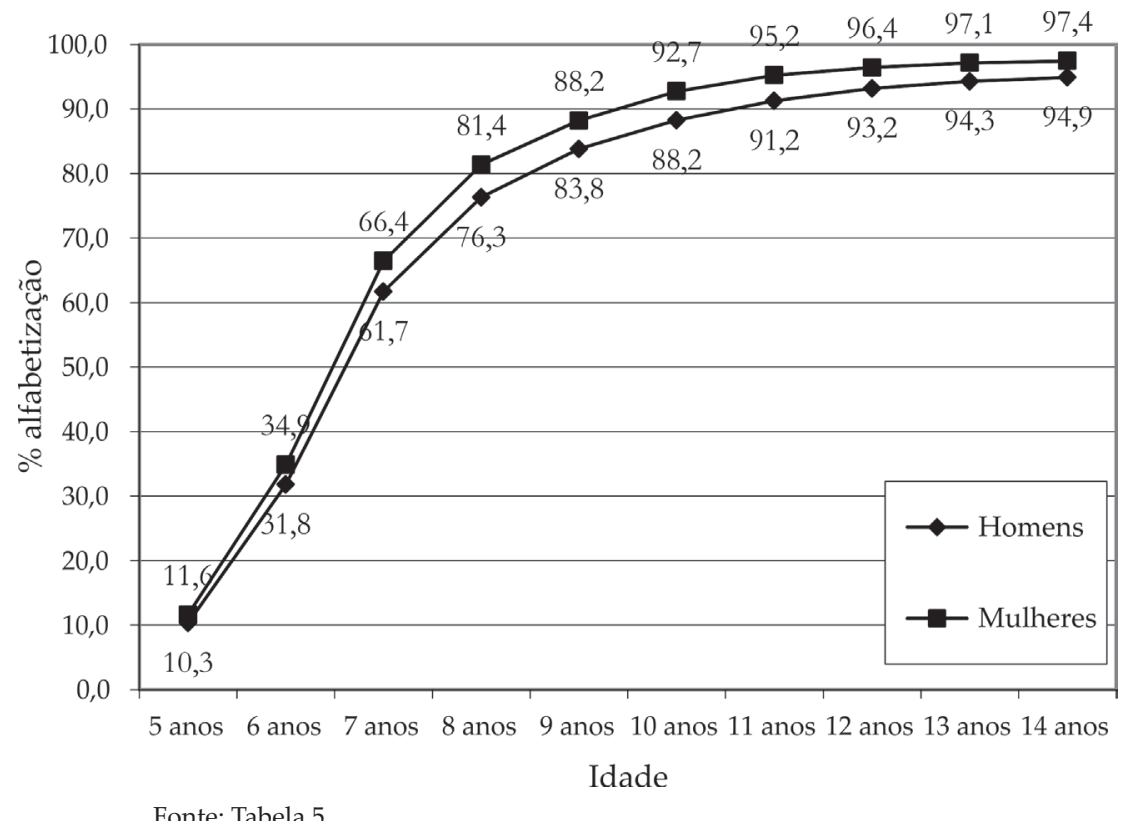




\section{Tabela 6}

Trajetória da taxa de alfabetização entre as pessoas de 5 a 14 anos, segundo a idade, por cor ou raça. Brasil, 2000.

\begin{tabular}{|c|c|r|r|r|rr|}
\hline \multirow{2}{*}{ Idade } & \multicolumn{6}{|c|}{ Taxa de alfabetização (\%) } \\
\cline { 2 - 7 } & \multicolumn{7}{|c|}{ Brancos/as } & \multicolumn{3}{c|}{ Negros/as } \\
\cline { 2 - 8 } & Total & Alfabet. & $\%$ & Total & Alfabet. & $\%$ \\
\hline 5 anos & 1.732 .900 & 220.970 & 12,8 & 1.636 .502 & 147.846 & 9,0 \\
6 anos & 1.662 .842 & 661.119 & 39,8 & 1.594 .570 & 425.836 & 26,7 \\
7 anos & 1.650 .136 & 1.233 .768 & 74,8 & 1.602 .716 & 854.154 & 53,3 \\
8 anos & 1.621 .168 & 1.426 .815 & 88,0 & 1.580 .780 & 1.100 .633 & 69,6 \\
9 anos & 1.642 .913 & 1.521 .977 & 92,6 & 1.573 .971 & 1.247 .598 & 79,3 \\
10 anos & 1.662 .177 & 1.582 .687 & 95,2 & 1.629 .095 & 1.396 .881 & 85,7 \\
11 anos & 1.700 .943 & 1.642 .855 & 96,6 & 1.697 .560 & 1.527 .272 & 90,0 \\
12 anos & 1.710 .125 & 1.664 .905 & 97,4 & 1.753 .582 & 1.620 .627 & 92,4 \\
13 anos & 1.695 .701 & 1.658 .730 & 97,8 & 1.723 .644 & 1.615 .377 & 93,7 \\
14 anos & 1.733 .300 & 1.697 .696 & 97,9 & 1.777 .035 & 1.679 .430 & 94,5 \\
\hline
\end{tabular}

Fonte: IBGE, Censo Demográfico 2000. Microdados.

\section{Gráfico 6}

Trajetória da taxa de alfabetização entre as pessoas de 5 a 14 anos, segundo a idade, por cor ou raça. Brasil, 2000.

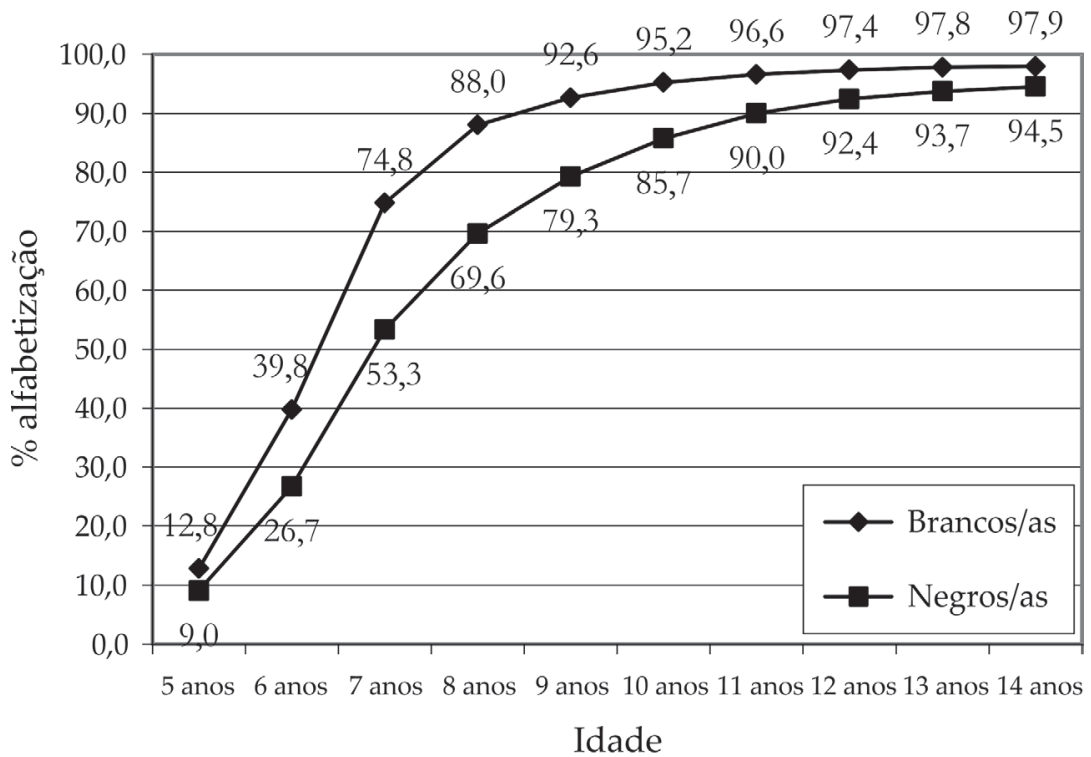

Fonte: Tabela 6. 
O Gráfico 6 contempla a dimensão cor ou raça. Nele, pode-se perceber com clareza que a desigualdade que atinge as crianças negras em relação às brancas é bem mais acentuada do que aquela apurada entre meninos e meninas. Com efeito, a desigualdade, que já é de quase 4 pontos percentuais aos 5 anos, sobe rapidamente para 13 pontos aos 6 anos e mais de 21 pontos aos 7 anos, passando, a partir dos 8 anos, a diminuir sucessivamente para cerca de 18, de 13 e de 9,5 pontos, até ficar reduzida a menos de 3 pontos percentuais no grupo de 14 anos. Isto, novamente, por conta das taxas estarem se aproximando de $100 \%$. Com outros indicadores, como ensino fundamental completo, as diferenças provavelmente permaneceriam bem mais elevadas.

A Tabela 7 e o Gráfico 7 permitem confrontar entre si as trajetórias das taxas de alfabetização dos 5 aos 14 anos, respectivamente para homens brancos, homens negros, mulheres brancas e mulheres negras.

- A vantagem das meninas em relação aos meninos quanto à taxa de alfabetização manifesta-se tanto entre brancos/as como entre negros/as. Mais acentuadamente, porém, entre crianças negras.

- A desigualdade quanto à alfabetização é mais acentuada entre brancos/as e negros/as do que entre mulheres e homens, aspecto este que não pode ser ignorado ao se pensar em políticas afirmativas. Mas, sem que isto signifique que não se deva atentar para as desigualdades que afetam a população masculina em relação à feminina, fenômeno este que costuma ser lido como "fracasso dos meninos" (p. ex., Carvalho, 2004).

- É na idade de 7 anos que as desigualdades atingem seu ponto máximo em termos de taxa de alfabetização, figurando em primeiro lugar as mulheres brancas $(76,3 \%)$, seguidas pelos homens brancos $(73,2 \%)$, vindo bem abaixo as mulheres negras (56,3\%) e, finalmente, os homens negros $(50,5 \%)$. Ressalvando a pequena diferença em favor das mulheres em relação aos homens de mesma cor ou raça, pode-se dizer o seguinte: enquanto entre crianças brancas de 7 anos há três alfabetizadas em cada quatro (3/4), entre crianças negras essa proporção é bem mais baixa - de apenas uma em cada duas $(1 / 2)$.

\section{Introduzindo a dimensão classe social}

Um experimento de cruzamento das dimensões gênero, cor ou raça e classe com escolaridade foi feito recentemente pelo autor (Ferraro, 2009a). Retomar aqui esse tipo de processamento e análise demandaria mais tempo do que o disponível e levaria a ultrapassar a extensão admissível de um artigo. Por isso, a análise que segue limitase a um recorte na questão das desigualdades entre classes e frações de classe. 


\section{Tabela 7}

Trajetória da taxa de alfabetização entre as pessoas de 5 a 14 anos, segundo a idade, por sexo e cor ou raça. Brasil, 2000.

\begin{tabular}{|c|c|c|c|c|c|c|c|c|c|c|c|c|}
\hline \multirow{4}{*}{ Idade } & \multicolumn{12}{|c|}{ Taxa de alfabetização (\%) } \\
\hline & \multicolumn{6}{|c|}{ Homens } & \multicolumn{6}{|c|}{ Mulheres } \\
\hline & \multicolumn{3}{|c|}{ Brancos } & \multicolumn{3}{|c|}{ Negros } & \multicolumn{3}{|c|}{ Brancas } & \multicolumn{3}{|c|}{ Negras } \\
\hline & Total & Alf. & $\%$ alf. & Total & Alf. & $\begin{array}{c}\% \\
\text { alf. }\end{array}$ & Total & Alf. & $\begin{array}{c}\% \\
\text { alf. }\end{array}$ & Total & Alf. & $\%$ alf. \\
\hline 5 anos & 864.568 & 105.338 & 12,2 & 845.373 & 70.863 & 8,4 & 868.331 & 115.631 & 13,3 & 791.129 & 76.983 & 9,7 \\
\hline 6 anos & 831.259 & 322.224 & 38,8 & 823.487 & 205.045 & 24,9 & 831.583 & 338.894 & 40,8 & 771.083 & 220.791 & 28,6 \\
\hline 7 anos & 821.680 & 601.754 & 73,2 & 826.130 & 417.105 & 50,5 & 828.455 & 632.014 & 76,3 & 776.586 & 437.049 & 56,3 \\
\hline 8 anos & 810.472 & 701.944 & 86,6 & 820.691 & 544.874 & 66,4 & 810.696 & 724.871 & 89,4 & 760.089 & 555.759 & 73,1 \\
\hline 9 anos & 821.252 & 751.843 & 91,5 & 812.641 & 619.446 & 76,2 & 821.661 & 770.134 & 93,7 & 761.331 & 628.153 & 82,5 \\
\hline 10 anos & 841.318 & 792.147 & 94,2 & 849.523 & 701.680 & 82,6 & 820.860 & 790.540 & 96,3 & 779.572 & 695.201 & 89,2 \\
\hline 11 anos & 853.713 & 816.816 & 95,7 & 874.201 & 761.090 & 87,1 & 847.231 & 826.039 & 97,5 & 823.357 & 766.181 & 93,1 \\
\hline 12 anos & 854.392 & 825.770 & 96,7 & 893.701 & 804.423 & 90,0 & 855.733 & 839.135 & 98,1 & 859.881 & 816.204 & 94,9 \\
\hline 13 anos & 837.778 & 814.422 & 97,2 & 876.817 & 802.846 & 91,6 & 857.922 & 844.307 & 98,4 & 846.826 & 812.531 & 96,0 \\
\hline 14 anos & 855.764 & 832.695 & 97,3 & 907.629 & 841.357 & 92,7 & 877.536 & 865.001 & 98,6 & 869.405 & 838.073 & 96,4 \\
\hline
\end{tabular}

Fonte: IBGE. Censo Demográfico 2000. Microdados.

\section{Gráfico 7}

Trajetória da taxa de alfabetização entre as pessoas de 5 a 14 anos, segundo a idade, por sexo e cor ou raça. Brasil, 2000.

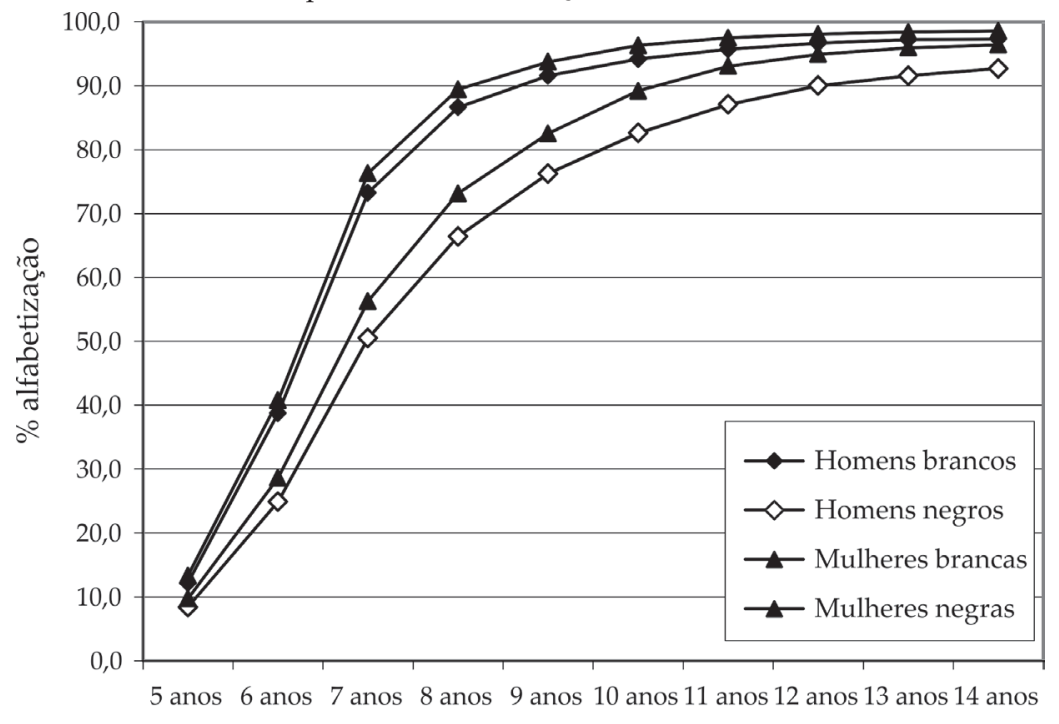

Fonte: Tabela 7.

Idade 
Processamento feito do Censo 2000 dá, por exemplo, para jovens de 20 anos de idade, as seguintes taxas de realização do ensino fundamental completo, segundo a situação na ocupação: empregadores: $80,0 \%$; empregados com carteira assinada: 73,3\%; empregados sem carteira assinada: $54,4 \%$; conta própria: $42,0 \%$; trabalhadores domésticos com e sem carteira assinada: $38,6 \%$; outros: $25,2 \%$.

A taxa de conclusão do ensino fundamental entre os jovens empregadores de 20 anos é 3,2 vezes mais elevada $(80,0 \%)$ do que a taxa verificada na categoria outros $(25,2 \%)$ e cerca de duas vezes mais elevada do que aquela apresentada pelas categorias conta própria e trabalhadores domésticos com e sem carteira assinada. Mesmo entre diferentes categorias da classe trabalhadora as diferenças são enormes, variando, por exemplo, a taxa de conclusão do ensino fundamental de 73,3\% entre empregados com carteira assinada, para apenas 38,6\% entre trabalhadores domésticos com ou sem carteira assinada. Isto para dizer o quanto é equivocada a posição daquelas e daqueles que insistem em dar por superada a perspectiva de classes no estudo das desigualdades sociais em geral e das desigualdades educacionais em particular.

Dito isso, passa-se a considerar apenas o grupo ocupacional definido pelo IBGE como empregados com carteira assinada. Dentro de todo o conjunto de categorias correntemente denominadas classe trabalhadora, isto é, a classe que vive da venda de sua força de trabalho por um salário, os empregados com carteira assinada constituem o grupo em condições relativamente melhores, porque inserido no mercado formal de trabalho. Este grupo compreende todo o funcionalismo público, assim como todos os trabalhadores formais (com carteira assinada) dos mais diversos ramos e níveis do setor privado. No Censo 2000, compunham esse grupo, o mais numeroso, 22.247.983 trabalhadores. A esse grupo se contrapunham, naquele mesmo ano, aproximadamente 15,5 milhões de empregados sem carteira assinada, 15,1 milhões por conta própria, 1,5 milhão de trabalhadores domésticos com carreira assinada e 3,4 milhões de trabalhadores domésticos sem carteira assinada, além de outras categorias ainda mais fragilizadas, como a dos não remunerados em ajuda a membros do domicílio e trabalhadores na produção para o próprio consumo, com respectivamente 4,6 e 2,2 milhões (IBGE, 2000).

A Tabela 8 apresenta os números absolutos e relativos de empregados/as de 15 a 24 anos de idade, com carteira assinada, que, no Censo de 2000, tinham pelo menos ensino fundamental completo, classificados conforme as quatro categorias de sexo e cor ou raça, já anteriormente utilizadas. Este grupo, todo ele escolarizado sob a vigência da Constituição de 1988, poderia (deveria!) ter concluído, no momento da pesquisa, pelo menos o ensino fundamental. O resultado, representado no Gráfico 8 , surpreende sob vários pontos de vista.

Primeiro, entre as pessoas de 15 anos, a taxa mais alta de conclusão do ensino fundamental completo, que se verifica entre as mulheres brancas, não vai além de $63,7 \%$. 


\section{Tabela 8}

Trajetória da taxa de pessoas de 15 a 24 anos, empregadas com carteira de trabalho assinada, com 8 anos ou mais de estudo, por idade, sexo e cor ou raça. Brasil, 2000.

\begin{tabular}{|c|c|c|c|c|c|c|c|c|c|c|c|c|}
\hline \multirow{4}{*}{ Idade } & \multicolumn{12}{|c|}{8 anos ou mais de estudo } \\
\hline & \multicolumn{6}{|c|}{ Homens } & \multicolumn{6}{|c|}{ Mulheres } \\
\hline & \multicolumn{3}{|c|}{ Brancos } & \multicolumn{3}{|c|}{ Negros } & \multicolumn{3}{|c|}{ Brancas } & \multicolumn{3}{|c|}{ Negras } \\
\hline & Total & Alfab. & $\%$ & Total & Alfab. & $\begin{array}{c}\% \\
\text { alfab. }\end{array}$ & Total & Alfab. & $\begin{array}{c}\% \\
\text { alfab. }\end{array}$ & Total & Alfab. & $\begin{array}{c}\% \\
\text { alfab. }\end{array}$ \\
\hline 15 anos & 17.159 & 8.555 & 49,9 & 8.917 & 2.623 & 29,4 & 8.132 & 5.178 & 63,7 & 3.082 & 1.428 & 46,3 \\
\hline 16 anos & 65.307 & 41.536 & 63,6 & 32.184 & 14.467 & 45,0 & 33.621 & 26.959 & 80,2 & 12.200 & 8.294 & 68,0 \\
\hline 17 anos & 112.425 & 77.562 & 69,0 & 59.642 & 29.280 & 49,1 & 69.458 & 58.931 & 84,8 & 25.886 & 19.180 & 74,1 \\
\hline 18 anos & 168.462 & 120.168 & 71,3 & 96.641 & 49.176 & 50,9 & 121.181 & 107.978 & 89,1 & 43.280 & 34.920 & 80,7 \\
\hline 19 anos & 222.132 & 162.368 & 73,1 & 137.198 & 74.038 & 54,0 & 158.637 & 142.530 & 89,8 & 61.792 & 50.927 & 82,4 \\
\hline 20 anos & 274.740 & 195.697 & 71,2 & 180.913 & 98.726 & 54,6 & 191.774 & 172.183 & 89,8 & 79.686 & 66.609 & 83,6 \\
\hline 21 anos & 286.354 & 200.581 & 70,0 & 195.723 & 103.326 & 52,8 & 196.492 & 175.813 & 89,5 & 84.876 & 70.272 & 82,8 \\
\hline 22 anos & 299.278 & 205.303 & 68,6 & 216.121 & 111.146 & 51,4 & 205.048 & 182.092 & 88,8 & 92.679 & 76.378 & 82,4 \\
\hline 23 anos & 296.689 & 198.576 & 66,9 & 217.590 & 109.300 & 50,2 & 203.216 & 177.972 & 87,6 & 94.495 & 76.367 & 80,8 \\
\hline 24 anos & 298.876 & 196.399 & 65,7 & 223.723 & 108.008 & 48,3 & 201.486 & 174.661 & 86,7 & 91.443 & 72.815 & 79,6 \\
\hline
\end{tabular}

Fonte: IBGE. Censo Demográfico 2000. Microdados.

\section{Gráfico 8}

Trajetória da taxa de pessoas de 15 a 24 anos, empregadas com carteira de trabalho assinada, com 8 anos ou mais de estudo, por idade, sexo e cor ou raça. Brasil, 2000.

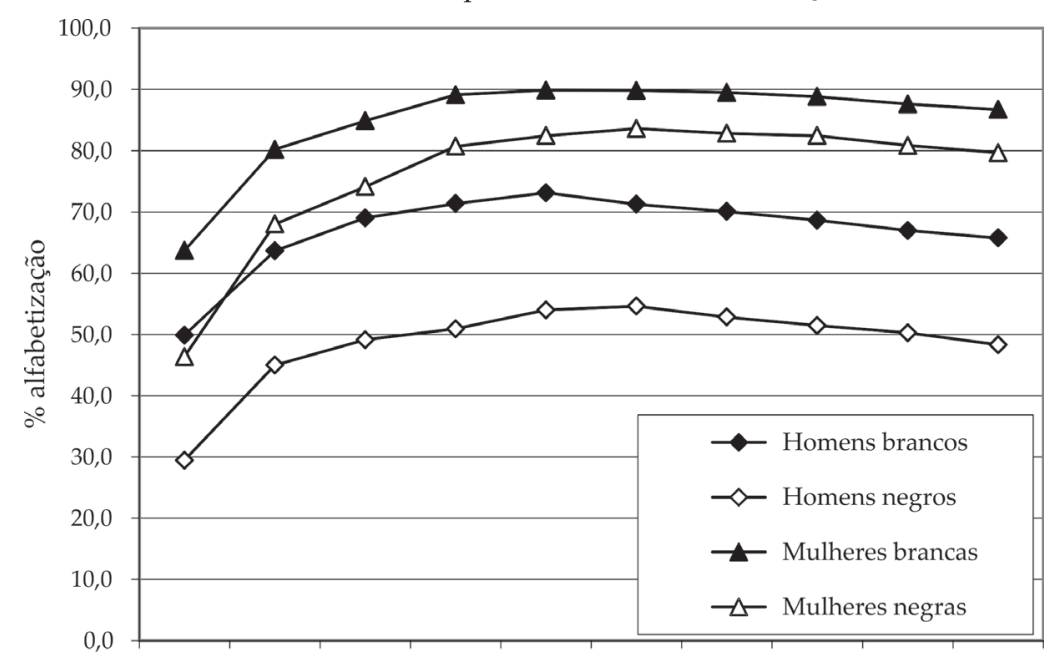

15 anos 16 anos 17 anos 18 anos 19 anos 20 anos 21 anos 22 anos 23 anos 24 anos Idade

Fonte: Tabela 8 . 
Segundo, entre as mesmas pessoas de 15 anos de idade, a taxa de realização do ensino fundamental completo de parte das mulheres brancas $(63,7 \%)$ representa mais do que o dobro daquela obtida pelos homens negros $(29,4 \%)$, situados no extremo oposto da escala.

Terceiro, as mulheres negras, exceção feita para a idade de 15 anos, apresentam percentuais mais elevados de realização do ensino fundamental completo do que os homens brancos, vantagem esta (das mulheres negras) que se acentua rapidamente a partir dos 16 anos e que, depois, se mantém mais ou menos constante a partir dos 20 anos.

Quarto, o resultado das três observações anteriores é que, no grupo de idade de 15 a 24 anos, pode-se perceber claramente quatro patamares distintos de taxas percentuais de conclusão do ensino fundamental, ocupando as mulheres - brancas e negras - os dois patamares mais elevados, com a seguinte ordem decrescente: $1^{1}$ - mulheres brancas; $2^{\underline{0}}$ - mulheres negras; $3^{-0}$ - homens brancos; $4^{\circ}-$ homens negros. Entre os/as trabalhadores/as de 20 anos com carteira assinada, por exemplo, as diferenças entre as taxas de conclusão do ensino fundamental são gritantes, em prejuízo principalmente para os homens negros: mulheres brancas: $89,8 \%$; mulheres negras: $83,6 \%$; homens brancos: $71,2 \%$; homens negros: $54,6 \%$. A diferença, que é de apenas 6,2 pontos percentuais em favor das mulheres brancas em relação às mulheres negras, ascende para 12,4 pontos percentuais em favor das mulheres negras em relação aos homens brancos, e a 16,6 pontos percentuais em favor destes últimos em relação aos homens negros.

Questão de gênero ou questão de cor/raça? Repetir-se-á aqui interpretação desenvolvida em trabalho recente com base no Censo de 2000, envolvendo todas as categorias de trabalhadores assalariados, com ou sem carteira assinada:

De outro lado, em todas as quatro categorias de empregados e trabalhadores assalariados, com ou sem carteira assinada (Empregado com carteira de trabalho assinada, Empregado sem carteira de trabalho assinada, Trabalhador doméstico com carteira de trabalho assinada e Trabalhador doméstico sem carteira de trabalho assinada), as quais representam cerca de 2/3 da população ocupada, a relação de gênero é tão forte que chega a se sobrepor à de cor ou raça, a ponto de a mulher negra superar o homem branco [em termos de média de anos de estudo] em cada uma dessas quatro categorias, tendo-se a seguinte ordem: $1^{\mathrm{o}}$ lugar - mulher branca, 2을 lugar - mulher negra, $3^{\mathrm{o}}$ lugar - homem branco, $4^{\mathrm{o}}$ lugar - homem negro. (Ferraro, 2009a, p. 20)

Dizia-se também, no referido trabalho, que "seria no mínimo precipitado tomar a vantagem estatística das mulheres em relação aos homens quanto à educação escolar como prova de superação e até de inversão de sinal na desigualdade social que, historicamente, tem marcado, em desfavor das mulheres, as relações de gênero" (idem, ibid., p. 20). Dizia-se, por fim, que sucessivos debates com estudantes sobre este ponto tinham sugerido que "às mulheres são exigidos níveis de escolarização 
relativamente mais elevados do que aos homens para o mesmo posto de trabalho, especialmente se a competição envolve também a mesma remuneração" (p. 21).

Assim, se a mulher branca, justamente por ser mulher, é compelida a buscar mais educação para melhorar seu poder de competição no mercado de trabalho, a mulher negra ver-se-ia duplamente premida no mesmo sentido: por ser mulher e por ser negra. Isto explicaria por que as proporcionalmente poucas mulheres negras que, no Censo de 2000 (Tabela 6), haviam conseguido ingresso no mercado formal de trabalho, apresentavam taxas de conclusão do ensino fundamental bem mais elevadas do que os homens brancos, aproximando-se das taxas verificadas entre as mulheres brancas.

O que se acaba de mostrar e dizer deveria ser levado em conta na formulação e condução das políticas públicas, seja com vistas à superação do dito "fracasso dos meninos", seja voltadas para o objetivo de superar as desigualdades étnico-raciais.

\section{Finalizando}

A principal conclusão que se pode tirar das análises realizadas diz respeito tanto à multiplicidade de dimensões consideradas, quanto ao momento (idade) na vida das crianças em que se estabelecem as desigualdades relativamente à alfabetização e escolarização. Com efeito, se, de um lado, todas as dimensões consideradas (sexo, cor ou raça e classe), sem prejuízo de outras que não puderam ser levadas em conta neste estudo, têm influência no processo de escolarização e alfabetização, de outro, o estudo sugere que, qualquer que seja o impacto de cada uma dessas dimensões, o sucesso ou insucesso e, consequentemente, as desigualdades quanto à alfabetização e a continuidade nos estudos se definem na largada do processo de escolarização fundamental. Com tendência, acrescente-se, desse momento/idade vir a antecipar-se dos 7 para os 6 anos, na medida em que todos/as os/as alunos/as estejam incorporados no ensino fundamental de nove anos, com ingresso já aos 6 anos de idade.

Relacionada com a primeira, pode-se destacar uma segunda conclusão. Esta se refere à importância do indicador censitário de alfabetização - a (declaração de) capacidade de ler e escrever um bilhete simples. Não porque este seja um excelente indicador de alfabetização, mas pelo fato de ele captar, mesmo que não mais que isto, o sucesso ou insucesso na efetivação do primeiro passo no processo de escolarização fundamental e alfabetização.

Além dessas conclusões, haveria que registrar a consciência dos limites da tarefa realizada, limites estes que, a partir da apresentação da versão original do texto na 32 a Reunião Anual da ANPEd, em Caxambu (MG), em 2009, e dos debates então travados, se converteram em desafios para a pesquisa. 
O primeiro desafio, de focar a questão da alfabetização na ótica da relação entre público e privado, foi afastado desde o início, mediante negociação com o Grupo Alfabetização, Leitura e Escrita. Em que pese sua relevância e atualidade, esse tema não fazia parte da agenda de pesquisa do autor. Além disso, entendia-se que essa questão demandaria recurso a outro tipo de estatísticas educacionais - aquelas originadas dos registros escolares e relativas ao movimento do(s) sistema(s) escolar(es), coletadas pelos censos escolares do INEP, não aquelas obtidas através de levantamentos censitários e amostrais do IBGE, com informações sobre o estado educacional da população. Aquelas contemplam a dimensão do público e privado quanto a estabelecimentos escolares, infraestrutura, professores, alunos, rendimento, entre outros; as últimas, não. E quase toda a história de pesquisa do autor esteve afeta a estas, tendo como fontes especialmente os censos demográficos.

O segundo desafio tem a ver tanto com a ideia em si de se definir níveis de letramento, quanto com a informação ou critério adotado para tal fim. Mesmo que já se tivesse tentado definir níveis de letramento a partir da informação sobre anos de estudo (cf. Ferraro, 2002), na revisão optou-se por abandonar esta parte, porquanto o aprofundamento teórico e empírico do tema do letramento e de sua relação com a alfabetização demandaria no mínimo outro artigo.

O terceiro desafio é a questão regional. Onde, no Brasil, os avanços foram mais significativos? Onde foram menos? Quanto à alfabetização, um processamento preliminar para cada uma das Unidades da Federação, que não foi possível incluir neste trabalho, parece indicar que os avanços teriam sido maiores justamente nas unidades ou regiões menos alfabetizadas. Isto faria sentido, uma vez que, quanto mais uma unidade (país, estado ou município) se aproxima de $100 \%$ de alfabetização, tanto mais difícil se torna obter novos avanços. Aconteceria o mesmo se o indicador utilizado fosse, por exemplo, o ensino fundamental completo? Provavelmente, não. Esta é uma questão a investigar.

O quarto desafio - o maior deles, talvez - refere-se à possibilidade de se avaliar o efeito das políticas e projetos que vão se sucedendo no Brasil, país marcado por uma longa história de pequenos avanços - contínuos, mas lentos e graduais - no campo da educação escolar, à semelhança do retorno à democracia administrado pela ditadura militar. Quase a sugerir duas questões. A primeira: Que fatores têm impedido e/ou vêm impedindo avanços mais substanciais e mais rápidos no campo da escolarização? A segunda: Nas históricas condições políticas, econômicas, sociais e culturais do país, marcadas por enormes desigualdades de toda ordem, haveria como esperar avanços maiores e mais rápidos na escolarização? ${ }^{6}$

As críticas e sugestões recebidas quando da apresentação do trabalho na $32^{\underline{a}}$ Reunião Anual da ANPEd (2009) contribuíram muito para a revisão do texto, razão 
pela qual o autor expressa o seu agradecimento aos/às participantes, da mesma forma que registra mais uma vez o quanto o honrou o convite para a referida sessão.

\section{Notas}

1. Numa primeira versão, bem mais extensa, preparada para o Grupo de Trabalho Alfabetização, Leitura e Escrita, o trabalho foi apresentado na 32ª Reunião Anual da Associação Nacional de PósGraduação em Educação (ANPEd), em Caxambu (MG), em outubro de 2009. Nessa versão buscara-se articular o tema da alfabetização com o do letramento. Na revisão do texto, optou-se por limitá-lo à questão da alfabetização, pesando nessa decisão a percepção que o autor teve, quando da apresentação do trabalho, de que a questão do letramento parecia estar mais atrapalhando do que contribuindo para a comunicação e compreensão. Não pelo fato de considerá-la irrelevante, mas pela dificuldade de se conseguir abordar convenientemente mais esse aspecto no curto espaço de uma comunicação ou de um artigo. Com o mesmo objetivo de adequar a dimensão do texto aos padrões dos periódicos da área, optou-se por abandonar também a consideração dos estudos, no período delimitado, sobre as políticas e projetos direta ou indiretamente ligados ao tema da alfabetização.

2. Em relação a este ponto, o autor entende que a análise da trajetória da taxa de analfabetismo do primeiro censo (1872) ao último (2000) não oferece evidências de que tal mudança conceitual tenha comprometido, no nível aventado pelo IBGE, a comparabilidade entre os censos até 1940 e os que sobrevieram a partir de 1950 (Ferraro, 2002).

3. Para o ministro Goldemberg, no início da década de 1990, o analfabetismo de adultos já não era prioridade do Ministério da Educação. Segundo ele, alfabetizar o adulto não iria mudar a sua posição dentro da sociedade e poderia até perturbar. Propôs, por isso, concentrar recursos na alfabetização da população jovem, imaginando que, ao fazê-lo, em dez anos o analfabetismo desapareceria (apud Beisiegel, 1997).

4. A Lei n. 11.274, de 6 de fevereiro de 2006, alterou a redação dos artigos 29, 30, 32 e 87 da Lei n. 9.394, de 20 de dezembro de 1996, que estabelece as diretrizes e bases da educação nacional, dispondo sobre a duração de 9 (nove) anos para o ensino fundamental, com matrícula obrigatória a partir dos 6 (seis) anos de idade (Brasil, 2006).

5. Com efeito, na faixa de 5 a 14 anos, a PNAD de 2007 apresenta taxas de alfabetização inferiores às verificadas na PNAD de 2006 (IBGE, respectivamente 2007 e 2006).

6. Esta última questão foi amplamente trabalhada no texto "Liberalismos e educação. Ou por que o Brasil não podia ir além de Mandeville" (Ferraro, 2009c).

\section{Referências}

BEISIEGEL, C.R. Considerações sobre a política da União para a educação de jovens e adultos analfabetos. Revista Brasileira de Educação, Rio de Janeiro; Campinas, n. 4, p. 26-34, jan./abr. 1997.

BRASIL. Constituição (1988). Constituição da República Federativa do Brasil. Brasília, DF: Senado, 1988. Disponível em: <http://www.planalto.gov.br/ccivil_03/Constituicao/Constituiçao.htm>. Acesso em: 6 mar. 2010.

BRASIL. Lei n. 11.274, de 6 de fevereiro de 2006. Altera a redação dos arts. 29, 30, 32 e 87 da Lei no 9.394, de 20 de dezembro de 1996, que estabelece as diretrizes e bases 
da educação nacional, dispondo sobre a duração de 9 (nove) anos para o ensino fundamental, com matrícula obrigatória a partir dos 6 (seis) anos de idade. Diário Oficial da União, Brasília, DF, 7 fev. 2006. Disponível em: <http://www3.dataprev.gov. br/sislex/paginas/42/2006/11274.htm>. Acesso em: 8 dez. 2009.

CARVALHO, M.P. Quem são os meninos que fracassam na escola? Cadernos de Pesquisa, São Paulo, v. 34, n. 121, p. 11-40, jan./abr. 2004.

CIPOLLA, C. Educación y desarrollo en Occidente. Barcelona: Ariel, 1970.

FERRARO, A.R. Alfabetizar é escolarizar. Sociedade \& Estado, Brasília, DF, v. 14, n. 2, p. 323-348, jul./dez. 1999.

FERRARO, A.R. Analfabetismo e níveis de letramento no Brasil: o que dizem os censos? Educação \& Sociedade, Campinas, v. 23, n. 81, p. 21-47, dez. 2002.

FERRARO, A.R. Analfabetismo no Brasil: desconceitos e políticas de exclusão. Perspectiva, Florianópolis, v. 22, n. 1, p. 111-126, jan./jun. 2004.

FERRARO, A.R. Analfabetismo e alfabetização no Brasil: tendência secular e questões metodológicas. In: Santos, M.L.L.; Damiani, F.E. (Org.). Onde eles estão?: desvelando o analfabetismo no Brasil. Passo Fundo: UPF, 2005. p. 49-79.

FERRARO, A.R. Escolarização no Brasil: articulando as perspectivas de gênero, raça e classe social. In: INTERNATIONAL CONGRESS OF LATIN AMERICAN STUDIES ASSOCIATION, 2009, Rio de Janeiro. LASA 2009 Congress Archive. Pittsburg: University of Pittsburg, 2009a. p. 1-30.

FERRARO, A.R. História inacabada do analfabetismo no Brasil. São Paulo: Cortez, 2009b.

FERRARO, A.R. Liberalismos e educação: ou por que o Brasil não podia ir além de Mandeville. Revista Brasileira de Educação, Rio de Janeiro; Campinas, v. 14, n. 41, p. 308-325, maio/ago. 2009c.

FERRARO, A.R.; LEÃO, M. Lei Saraiva (1881): dos argumentos invocados pelos liberais para a exclusão dos analfabetos do direito de voto. In: CONGRESSO IBEROAMERICANO DE HISTÓRIA DA EDUCAÇÃO LATINO-AMERICANA, 19., 2009, Rio de Janeiro. Anais... Rio de Janeiro, sBHE, 2009. p.1-8.

FURET, F.; OZOUF, J. (Dir.). Lire e écrire: l'alphabétization des français de Calvin à Jules Ferry. Paris: Minuit, 1977.

INSTITUTO BRASILEIRO DE GEOGRAFIA E ESTATÍSTICA (IBGE). Censo Demográfico 1950: Brasil. Rio de Janeiro: IBge, 1956. (Serie Nacional, v.1). 
INSTITUTO BRASILEIRO DE GEOGRAFIA E ESTATÍSTICA (IBGE). Conselho Nacional de Estatística. Contribuições para o estudo da demografia no Brasil. Rio de Janeiro: IBGE, 1961. Parte G - Alfabetização, p. 387-448.

INSTITUTO BRASILEIRO DE GEOGRAFIA E ESTATÍSTICA (IBGE). Censo Demográfico 1991. Rio de Janeiro: IBGE, 1991.

INSTITUTO BRASILEIRO DE GEOGRAFIA E ESTATÍSTICA (IBGE). Censo Demográfico 2000. Rio de Janeiro: IBGE, 2001. (DVD de microdados).

INSTITUTO BRASILEIRO DE GEOGRAFIA E ESTATÍSTICA (IBGE). Censo Demográfico 2000: Características da população e dos domicílios; resultados do universo. Rio de Janeiro: IBGE, 2001.

INSTITUTO BRASILEIRO DE GEOGRAFIA E ESTATÍSTICA (IBGE). Pesquisa Nacional por Amostra de Domicílios 1990, ... 1992, ... 1995, ... 1999, ... 2003, ... 2006, ... 2007, ... 2008. Rio de Janeiro: IBGe. (CD de microdados).

ORGANISATION DES NATIONS UNIES POUR L'EDUCATION, LA SCIENCE ET LA CULTURE (UNESCO). L'analphabétisme dans divers pays : étude statistique préliminaire sur la base des recensements effectuées depuis 1900. Paris: unESCO, 1953.

TORRES, R.M. Analfabetismo y alfabetización en América Latina y Caribe: entre la inercia y la ruptura. Perspectives, Paris, v. 20, n. 4, p. 511-518, 1990.

Recebido em 30 de julho de 2010.

Aprovado em 29 de abril de 2011. 